\title{
Volatile Terpenoids from Water Pepper (Polygonum punctatum) Against Pseudomonas aeruginosa and Staphylococcus aureus Virulence Strategies
}

\author{
M. Gilabert ${ }^{\mathrm{a}, \mathrm{b}}$, E. Cartagena ${ }^{\mathrm{b}}, \mathrm{G}$. Escobar $^{\mathrm{b}}$, A. Bardón ${ }^{\mathrm{a}, \mathrm{b}}$ and M.E. Arena ${ }^{\mathrm{a}, \mathrm{b},{ }^{*}}$ \\ a Instituto de Química del Noroeste - Centro Científico Tecnológico Tucumán. Consejo Nacional de \\ Investigaciones Científicas y Tecnológicas (CONICET). Ayacucho 471, Tucumán, 4000, Argentina \\ ${ }^{b}$ Facultad de Bioquímica, Química y Farmacia, Universidad Nacional de Tucumán (UNT), Ayacucho 471, \\ Tucumán, 4000, Argentina
}

\begin{abstract}
Polygonum punctatum Elliot (water pepper) is a pungent herb ancestrally employed as a disinfectant in traditional medicine by Toba Indians of the north-eastern region of Argentina and also commonly used as spice in Japanese cuisine. GC-MS of whole diethyl ether extract (EE) from aerial parts allowed to identify 14 volatile terpenoids such as sesquiterpenes: $\alpha$-bisabolol (3.4\%), polygodial and isotadeonal (34.0\%); various methylated phenol like $\alpha$ tocopherol or vitamin E (3.6 \%), and phytosterols: stigmasterol $(2.1 \%)$ and $\beta$-sitosterol $(29.9 \%)$. Thus, water pepper is a promising source of drimane sesquiterpenes and phytoestrogens with important bioactivities.

Following a taste- guided fractionation by CC and HPLC, drimane-type sesquiterpenes, polygodial (1) and its stereoisomer isotadeonal (2) were isolated as main compounds from the EE. The antipathogenic effects on the bacterial growth, biofilm formation, and elastase activity of both pure compounds and EE were evaluated against two Staphylococcus aureus and two Pseudomonas aeruginosa strains at 10 and $100 \mu \mathrm{g} / \mathrm{mL}$.

The highest effects were observed for the non pungent drimane isotadeonal (2) which was able to reduce about $75 \%$ the bacterial growth of all tested microorganisms and to inhibit Gram-positive biofilm formation (85 \% mean) at 100 $\mu \mathrm{g} / \mathrm{mL}$. In addition, elastase activity of $P$. aeruginosa, another virulence strategy, was attenuated more than $50 \%$ at 100 $\mu \mathrm{g} / \mathrm{mL}$ by 2 .

These results provide evidence that support the antimicrobial use of $P$. punctatum against $P$. aeruginosa and $S$. aureus, as well as, demonstrating that isotadeonal (2), despite it has been suggested to lack biological properties, is a bioactive compound able to control biofilm formation and bacterial growth of both human pathogens.
\end{abstract}

Keywords: Isotadeonal, biofilm, Polygonum punctatum, Pseudomonas aeruginosa, Staphylococcus aureus.

\section{INTRODUCTION}

The genus Polygonum (Polygonaceae), which comprises about 300 species [1], is worldwide distributed in temperate climates and it is represented in Argentina by 21 species [2]. It is a cosmopolitan plant that grows in damp places and shallow water of America, Australia, New Zealand, temperate Asia and Europe. The Polygonum genus is well known for producing a variety of secondary metabolites including flavonoids, triterpenoids, anthraquinones, coumarins, phenylpropanoids, tannins, and drimanes $[1,3]$.

The unsaturated dialdehyde (-)-polygodial, which posses a drimane backbone, has been found to be responsible for the pungent taste of some species of the genus, and hence for its uses as a spice. Polygodial is also a component of the "hot" taste in peppery spices common in traditional Japanese cuisine. In addition, polygodial is one of the main

*Address correspondence to this author at the Facultad de Bioquímica, Química y Farmacia, Universidad Nacional de Tucumán (UNT), Ayacucho 471, Tucumán, 4000, Argentina; Tel: 054-381-4247752; Fax: 054-381-4248169;

E-mail: arename@fbqf.unt.edu.ar bioactive compounds in many of the plants used in traditional medicine in Japan, China, Africa, and Brazil [4]. Furthermore, it has proven that is capable of acting against a notable variety of bacteria and fungi such as Saccharomyces cerevisiae, Candida albicans, and Salmonella $[5,6]$. This drimane compound has been reported for five species of the Polygonum genus: $P$. punctatum, $P$. hydropiper, $P$. acuminatum, and $P$. persicaria, and it was recognized as a key molecule that plays an important role in plants defense against predators, being fungitoxic, antifeedant against insects, as well as inhibiting the transmission of some viruses $[2,7]$.

Particularly, P. punctatum (water pepper, ajicillo, erva do bicho, caa-tai) which is used as a disinfectant in traditional medicine by Toba Indians of the northeastern region of Argentina [8], demonstrated to be effective against a broad spectrum of microorganisms that includes Staphylococcus aureus, Bacillus subtilis, Micrococcus luteus, Aspergillus niger and Mucor sp. [9].

Bacterial biofilms are complex communities of bacteria embedded in a self-produced matrix and 
attached to inert or living surfaces [10]. These microorganism communities are more resistant to the immune system and to antibiotics than planktonic or free-floating bacteria. There are a few studies in which chemical compounds with a strong biofilm-specific inhibition were identified [11]. A previous report indicates that drimane-type sesquiterpenes can be promising substances to biofilm formation control [12].

Pseudomonas elastase is a metalloprotease also known as pseudolysin or LasB which has long been recognized as a key virulence factor produced by $P$. aeruginosa [13]. LasB acts within the bacterial cell as a regulator in the generation of the secreted polysaccharides that constitute the bacterial biofilm. In addition, this enzyme degrades a broad range of host tissue proteins and biomolecules involved in innate immunity such as immunoglobulins, complement factors and cytokines. Thus LasB inhibition could be important for attenuation of Pseudomonas virulence [14].

Herein, volatile compounds from an Argentinean collection of Polygonum punctatum were investigated. Following a taste- guided fractionation, drimane-type sesquiterpenes were isolated as main compounds from a diethyl ether extract (EE) of this spicy herb. Antipathogenic properties of EE and its drimane-type sesquiterpene dialdehydes, polygodial (1) and its nonpungent stereoisomer isotadeonal (known as isopolygodial, 2), were determined against four pathogenic bacteria. EE and 1 and $\mathbf{2}$ were screened in their ability to control bacterial growth, biofilm formation, and elastase activity of two strains of $P$. aeruginosa, one of them from a clinically isolated. Furthermore, antibacterial and antibiofilm activities were measured on two strains of $S$. aureus (one of them methicillin-resistant).

\section{MATERIALS AND METHODS}

\subsection{General}

GC analysis was carried out using a TRACE GC chromatograph (Thermo Scientific, TX, USA). Lowresolution MS spectra were recorded using a POLARIS $Q$ instrument (Thermo Scientific, TX, USA). NMR spectra were measured in $\mathrm{CDCl}_{3}$ at $300 \mathrm{MHz}$ on a Bruker 300 spectrometer. The HPLC separations were performed on a Gilson apparatus, using a silica gel column Chemo Pack Develosil $60(5 \mu \mathrm{m}, 10 \mathrm{~mm}$ i.d. X $250 \mathrm{~mm}$ ) and a refractive index detector.

\subsection{Plant Material}

P. punctatum Elliot was collected in the Yungas region of Tucumán, Argentina. The air-dried aerial parts $(119.0 \mathrm{~g})$ were extracted at room temperature with agitation for 14 days with diethyl ether to give $6.0 \mathrm{~g}$ of residue after the solvent removal in a rotary evaporator (yield of $5 \%$ ). The EE was subjected to Sephadex $\mathrm{LH} 2 \mathrm{OCC}\left(\mathrm{MeOH}-\mathrm{CH}_{2} \mathrm{Cl}_{2}, 1: 1\right)$, silica gel CC (70-230 mesh) with $n$-hexane and increasing amounts of EtOAc $(0-100 \%)$, and finally $\mathrm{MeOH}$ as eluents. The elution was monitored using TLC on aluminiumprecoated plates with F254 indicator. The spots on the plates were visualised under UV light, and the plates were then sprayed with Godin reagent. It is known that polygodial has a similar retention factor (RF) in hexane-EtOAc 85:15 as cholesterol, and for this reason, cholesterol was used as a polarity reference. The eluates were tasted for their pungency. Fractions that eluted with a RF similar to cholesterol and with a pungent taste were combined, and this mixture was further processed using normal-phase HPLC (hexaneEtOAc17:3 at $1.5 \mathrm{~mL} / \mathrm{min}$ ).

\subsection{Microorganisms}

Four pathogenic bacteria were studied. Two of them were Staphylococcus aureus strains, and the other two Pseudomonas aeruginosa. S. aureus strains were ATCC $6538 \mathrm{P}$ and $S$. aureus methicillin-resistant F7; while $P$. aeruginosa strains were $P$. aeruginosa RPA100, isolated from an active infectious process (Collection of Facultad de Bioquímica, Química y Farmacia, Universidad Nacional de Tucumán, Argentina), and P. aeruginosa ATCC 27853.

\subsection{Bacterial Growth}

Overnight cultures of $P$. aeruginosa and $S$. aureus were diluted to reach an OD of $0.125 \pm 0.01$ at $600 \mathrm{~nm}$ in Luria-Bertani (LB) and Mueller-Hinton (MH) media, respectively. A $180 \mu \mathrm{L}$ aliquot of the diluted culture was placed in wells of a plastic microtitre plate. Solutions containing 0.1 and $0.01 \mathrm{mg} / \mathrm{mL}$ of EE, 1 , and 2 in a DMSO: distilled water mixture (1:1) were prepared separately, and $20 \mu \mathrm{L}$ of each solution was pipetted to the polystyrene microtitre plate wells individually ( 8 replicates). Negative control wells (8 replicates) contained $180 \mu \mathrm{L}$ of the diluted culture with $20 \mu \mathrm{L}$ of DMSO: water (1:1). The bacterial growth was detected as turbidity at $600 \mathrm{~nm}$ using a microtitre plate reader (Power Wave XS2; BioTek, Vermont, USA). 


\subsection{Biofilm Formation Assay}

For biofilm quantification, a micro-method based on a previously reported protocol was employed [15]. Biofilms formed after $24 \mathrm{~h}$ incubation of bacterial cultures prepared as described in the previous paragraph, were stained with $20 \mu \mathrm{L}$ of an aqueous solution of crystal violet, $(0.1 \% \mathrm{w} / \mathrm{v})$ for $20 \mathrm{~min}$. Then, the liquid was discarded from wells and the material that remained fixed to the plastic-polystyrene (containing biofilm) was washed with PBS (thrice). Crystal violet bound to biofilm was removed from each well employing $200 \mu \mathrm{L}$ of absolute ethanol during 30 min at $37^{\circ} \mathrm{C}$ with shaking. Absorbance $(540 \mathrm{~nm})$ of ethanol solutions of crystal violet was determined using a microtitre plate reader (Power Wave XS2. Biotek, Vermont, USA).

\subsection{Elastase B Activity}

Elastolytic activity was determined using a modification of a previously reported method [16]. Elastin Congo red $(100 \mu \mathrm{L})$ (Sigma) dissolved in Tris$\mathrm{HCl}(\mathrm{pH} 8.0)$ at a concentration of $5 \mathrm{mg} / \mathrm{mL}$ was mixed with $100 \mu \mathrm{L}$ cell-free culture supernatant from $P$. aeruginosa strains grown, during $24 \mathrm{~h}$, in LB media containing $100 \mu \mathrm{g} / \mathrm{mL}$ of $\mathrm{EE}$, polygodial, and isotadeonal. The reaction mixture $(200 \mu \mathrm{L})$ was incubated at $37^{\circ} \mathrm{C}$ for $24 \mathrm{~h}$ and centrifuged at 13,000 $\mathrm{rpm}$ for $10 \mathrm{~min}$. The absorbance $(495 \mathrm{~nm})$ of the supernatant is a measure of the enzyme activity.

\subsection{Statistical Analysis}

The experimental data were subjected to the analysis of variance (ANOVA) and the separation of means with least significance difference (LSD), using the One Way ANOVA and the parametric $T$ test of Student-Newman-Keuls at $95 \%$ level of confidence.

\section{RESULTS AND DISCUSSION}

\subsection{Chemical Analysis}

GC-MS analysis of the EE from aerial parts of $P$. punctatum has led to the identification of 14 plant volatile terpenoids (Table 1) such as sesquiterpenes: $\alpha$-bisabolol (3.4\%), polygodial and isotadeonal (34.0\%); various methylated phenol as $\alpha$-tocopherol or vitamin $\mathrm{E}(3.6 \%)$, and phytosterols: stigmasterol $(2.1 \%)$ and $\beta$-sitosterol (29.9\%). Thus water pepper is a promising source of drimane sesquiterpenes and phytoestrogens that containing important bioactivities.

The EE was further subjected to CC and HPLC combined methodologies to afford the drimane-type sesquiterpenes polygodial (1) and isotadeonal (2). Compounds were identified by their spectroscopic features after comparison with the available data in literature $[2,7,17]$.

When purified polygodial was analyzed by GC-MS two peaks were detected, one of the detected picks was identical to isotadeonal and the other one was

Table 1: GC-MS of Polygonum punctatum Constituents

\begin{tabular}{|c|c|c|c|}
\hline Compounds & Formula & $\mathrm{RT}(\min )$ & Area $(\%)$ \\
\hline$\beta$-Selinene & $\mathrm{C}_{15} \mathrm{H}_{24}$ & 22.9 & 1.5 \\
\hline$\beta$-Caryophillene & $\mathrm{C}_{15} \mathrm{H}_{24}$ & 24.2 & 1.7 \\
\hline Cis- $\alpha$-bisabolene & $\mathrm{C}_{15} \mathrm{H}_{24}$ & 25.7 & 0.1 \\
\hline Germacrene D & $\mathrm{C}_{15} \mathrm{H}_{24}$ & 26.8 & 0.2 \\
\hline$\gamma$-maaliene & $\mathrm{C}_{15} \mathrm{H}_{24}$ & 27.4 & 0.5 \\
\hline Cedrene & $\mathrm{C}_{15} \mathrm{H}_{24}$ & 28.5 & 2.4 \\
\hline Caryophillene oxide & $\mathrm{C}_{15} \mathrm{H}_{24} \mathrm{O}$ & 31.0 & 0.3 \\
\hline Spathulenol & $\mathrm{C}_{15} \mathrm{H}_{24} \mathrm{O}$ & 33.1 & 0.3 \\
\hline Agarospirol & $\mathrm{C}_{15} \mathrm{H}_{26} \mathrm{O}$ & 34.0 & 0.2 \\
\hline$\alpha$-Bisabolol & $\mathrm{C}_{15} \mathrm{H}_{26} \mathrm{O}$ & 34.9 & 3.4 \\
\hline Polygodial and isotadeonal & $\mathrm{C}_{15} \mathrm{H}_{22} \mathrm{O}_{2}$ & $42.7-46.4$ & 34.0 \\
\hline$\alpha$-Tocopherol & $\mathrm{C}_{29} \mathrm{H}_{50} \mathrm{O}_{2}$ & 60.6 & 3.6 \\
\hline Stigmasterol & $\mathrm{C}_{29} \mathrm{H}_{48} \mathrm{O}$ & 68.4 & 2.1 \\
\hline$\beta$-Sitosterol & $\mathrm{C}_{29} \mathrm{H}_{50} \mathrm{O}$ & 71.6 & 29.9 \\
\hline
\end{tabular}


identical to the original polygodial, thus the appearance of isotadeonal into the GC analysis of polygodial is probably an artifact. For this reason, in the total ion current chromatogram (TIC) of whole EE was impossible to determine the area relationships between both isomers [18].

Previous reports have suggested that isotadeonal (2) could be an artifact produced during the isolation process, and therefore it shouldn't be considered as a natural product [19]. However, in the present research was possible to detect the presence of both isomers into the EE by NMR before the application of any chromatographic process. This result is in agreement with previous studies that clearly indicate that $\mathbf{2}$ is a natural product. Indeed, isotadeonal was isolated as natural product from Polygonum hydropiper L. [20], Warburgia salutaris [17], and Capsicodendron dinisii [21]. Concentration ratios of isotadeonal/polygodial appear to be influenced by the vegetal species and collection time [22].

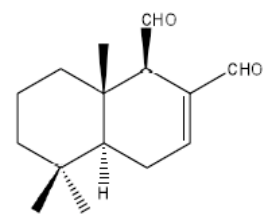

1

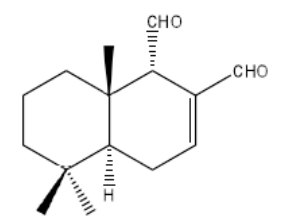

Figure 1: Chemical structures of drimanes from Polygonum punctatum. 1 - Polygodial, 2 - Isotadeonal (Isopolygodial).

\subsection{Antibacterial Activity}

$P$. aeruginosa ATCC 27853 bacterial growth was inhibited by 1 (polygodial), 2 (isotadeonal), and EE at
$100 \mu \mathrm{g} / \mathrm{mL}(22,68$, and $66 \%$, respectively), as shown in Figure 2. While, 2 and 1 at $10 \mu \mathrm{g} / \mathrm{mL}$ gave a bacterial growth inhibition of 21 and $7 \%$, respectively (data not shown). The $P$. aeruginosa multi-resistant strain growth was also inhibited by 2 and EE (86 and $35 \%$, respectively) at $100 \mu \mathrm{g} / \mathrm{mL}$. Neither performed tests showed bacterial growth inhibition at $10 \mu \mathrm{g} / \mathrm{mL}$ (data not shown).

Compound $2(100 \mu \mathrm{g} / \mathrm{mL})$ was also the most active drimane against $S$. aureus, which inhibited by $82 \%$ of S. aureus ATCC $6538 \mathrm{P}$ growth. While, EE inhibited by $67 \%$. Compound 1, also reduced the cell growth but only a $18 \%$ after $24 \mathrm{~h}$ incubation with respect to control, at the same concentration (Figure 2). Whereas, $S$. aureus methicillin-resistant F7 growth was inhibited $80 \%$ and $62 \%$ by 2 and EE, respectively. None of the treatments was able to inhibit $S$. aureus growth at 10 $\mu \mathrm{g} / \mathrm{mL}$ (data not shown).

It is important to note that $\mathbf{2}$ was able to produce a strong growth inhibition against all bacterial strains of this bioassay, while compound 1 only faintly reduced bacterial growth of ATCC strains, and did not significantly modify the bacterial growth of the resistant strains.

\subsection{Biofilm Inhibition}

Absorbance measurements of biofilm formed after $24 \mathrm{~h}$ incubation are shown in Figure 3. $P$. aeruginosa ATCC 27853 biofilm was inhibited by 26, 59, and $24 \%$ with $100 \mu \mathrm{g} / \mathrm{mL}$ of $\mathbf{1}, \mathbf{2}$, and EE, respectively. While, $P$. aeruginosa multi-resistant strain's biofilm was inhibited by 19,63 , and $31 \%$ in presence of $\mathbf{1}, \mathbf{2}$, and $E E$,

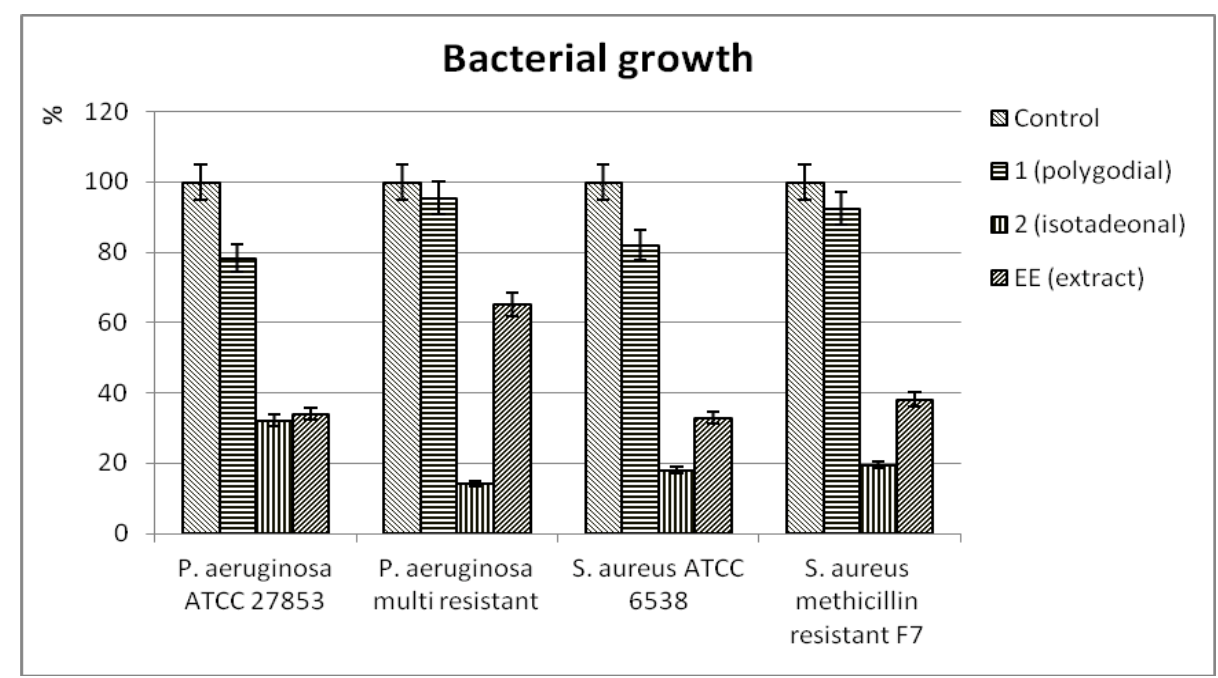

Figure 2: Effects of compounds 1 (polygodial), 2 (isotadeonal), EE (ethyl ether extract of Polygonum punctatum) at $100 \mu \mathrm{g} / \mathrm{mL}$, and negative control on Pseudomonas aeruginosa ATCC 27853, P. aeruginosa muti-resistant, Staphylococcus aureus ATCC 6538 P, and S. aureus F7 growth in Moeller Hinton medium. 


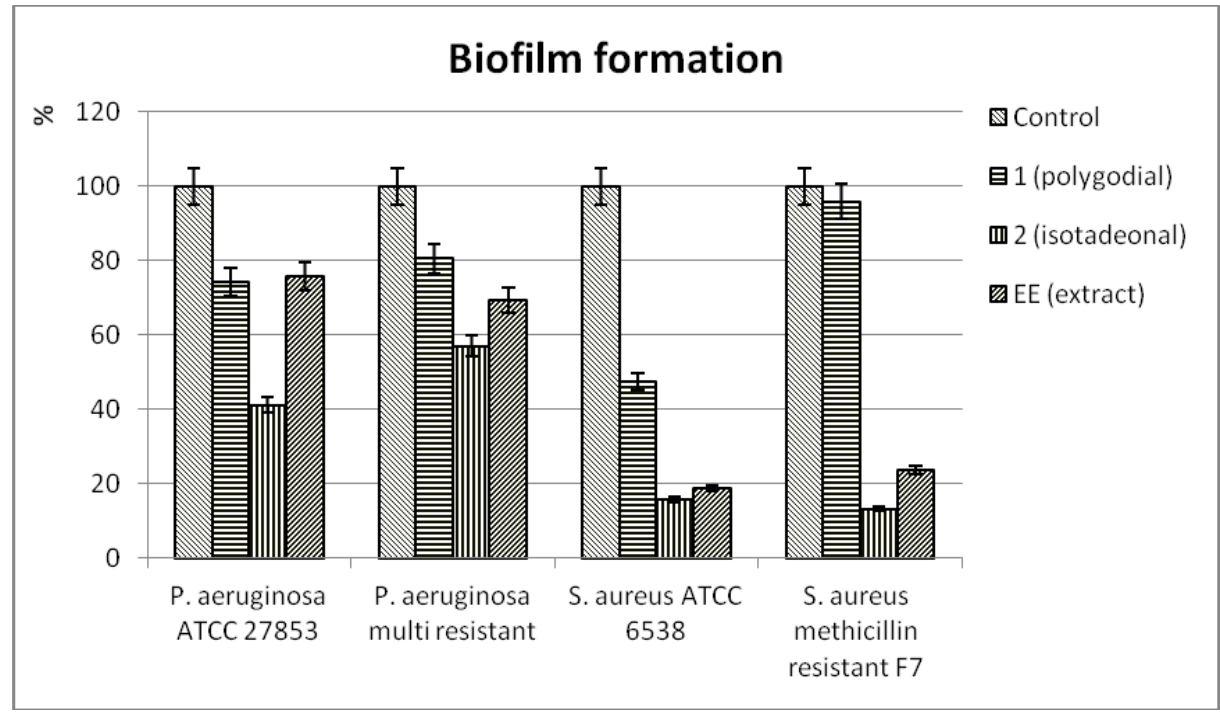

Figure 3: Effects of compounds 1 (polygodial), 2 (isotadeonal), EE (ethyl ether extract of Polygonum punctatum) at $100 \mu \mathrm{mg} / \mathrm{mL}$, and negative control on Pseudomonas aeruginosa ATCC 27853, P. aeruginosa muti-resistant, Staphylococcus aureus ATCC $6538 \mathrm{P}$, and S. aureus F7 biofilm formation measured as optical density at $540 \mathrm{~nm}$ after crystal violet staining in a microtitre plate test.

respectively (at the same concentration). Lower effects at $10 \mu \mathrm{g} / \mathrm{mL}$ of compounds or EE against $P$. aeruginosa ATCC 27853 were observed (about $30 \%$ ). None of the tested compounds or EE was able to inhibit significantly the $P$. aeruginosa multi-resistant biofilm at $10 \mu \mathrm{g} / \mathrm{mL}$ (data not shown).

S. aureus ATCC 6538 P biofilm formation decreased by 53,84 , and $81 \%$ in presence of 100 $\mu \mathrm{g} / \mathrm{mL}$ of 1,2 , and EE, respectively (Figure 3 ). As well as, the $S$. aureus $\mathrm{F} 7$ biofilm formation was reduced by 87 and $76 \%$, in presence of $100 \mu \mathrm{g} / \mathrm{mL}$ of 2 and $E E$, while polygodial (1) did not produce significant biofilm inhibition. Only EE at $10 \mu \mathrm{g} / \mathrm{mL}$ was able to produce slight biofilm formation inhibition (about $30 \%$ ) for both $S$. aureus strains (data not shown).

\subsection{Elastase B Inhibition}

Compounds 1, 2, and EE also inhibited the elastase B activity of $P$. aeruginosa ATCC 2785 by 48,76 and $52 \%$ at $100 \mu \mathrm{g} / \mathrm{mL}$, and 18,33 , and $19 \%$ at $10 \mu \mathrm{g} / \mathrm{mL}$, respectively. As well as, $P$. aeruginosa multi-resistant elastase activity decreased 24,56 , and $37 \%$ in presence of $100 \mu \mathrm{g} / \mathrm{mL}$ of 1,2 , and $E E$, respectively. At

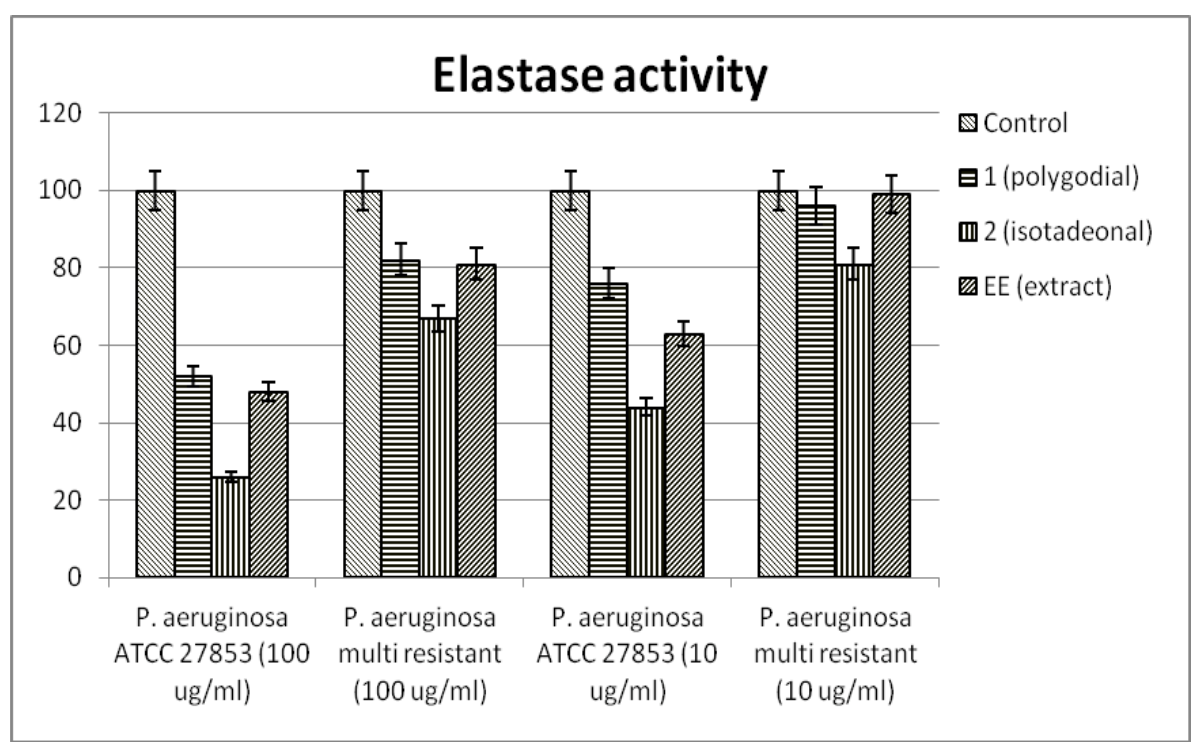

Figure 4: Effects of compounds 1 (polygodial), 2 (isotadeonal), EE (ethyl ether extract of Polygonum punctatum) at $100 \mu \mathrm{g} / \mathrm{mL}$ and $10 \mu \mathrm{g} / \mathrm{mL}$, and negative control on Pseudomonas aeruginosa ATCC 27853 and $P$. aeruginosa muti-resistant elastase activity measured as optical density at $495 \mathrm{~nm}$. 
$10 \mu \mathrm{g} / \mathrm{mL}$, only isotadeonal (2) was able to inhibit elastase activity (19\%), as shown in Figure 4.

Previous reports on the effects of polygodial against fungi established that its mechanism of action involve membrane disruption [23] and mitochondrial ATP synthase enzyme inhibition [24]. However, only a few studies about Polygonum compounds against pathogenic bacteria were carried out. The activity showed by the related specie $P$. cuspidatum, traditionally used in folk medicine to control oral diseases, against bacterial biofilm does not involve drimane compounds. A P. cuspidatum column fraction containing anthraquinones, cardiac glycosides, and phenolics compounds inhibits the biofilm of dental bacteria Streptococcus mutans and Streptococcus sobrinus [25].

It was previously reported that medicinal plant extracts, as well as some natural products, that displayed antibiotic activity against Gram-positive bacteria, lacked activity against Gram (-) bacteria $[26,27]$. It is worthy to point out that polygodial (1) and isotadeonal (2) were active against both, Gram-positive and negative bacteria, although they were more effective against Gram-positive strains.

As stated in previous reports [28], for both $S$. aureus and $P$. aeruginosa, ATCC isolates were more susceptible to the tested natural products than the clinical isolates. In these, the biofilm formation appears to provide a higher protection; e.g., polygodial inhibited the S. aureus ATCC $6538 \mathrm{P}$ biofilm by $53 \%$ at 100 $\mu \mathrm{g} / \mathrm{mL}$, while for the methicillin-resistant strain $F 7$, polygodial did no significantly modify the biofilm formation at the same concentration. Similar effects were observed for $P$. aeruginosa.

Among the tested compounds, isotadeonal (2) was the most active inhibitor, by reducing about $75 \%$ bacterial growth of all tested microorganisms. This may be indicative of a broad-spectrum antibiotic activity. In addition, 2 inhibited $85 \%$ (mean) Gram-positive strains' biofilms, and decreased the Gram-negative strains' elastase activity more than $50 \%$. The EE also showed an interesting activity, which can be explained not only by the important amounts of the active drimanes isotadeonal and polygodial in the EE, but also by the occurrence of spathulenol (see Table 1), a sesquiterpene that has proven to have antibacterial and anti-quorum sensing activity [29].

The important activity showed by isotadeonal adds new evidence to the fact reported by Anke and Sterner
[30] and Derita et al. [22], who determined that in contrast with previous suggestions [23] isotadeonal is clearly a bioactive compound, and more studies are needed to further characterize its full range of antibiotic and anti-pathogenic properties.

Given that drimanes from $P$. punctatum were effective to control bacterial growth of some human pathogenic bacteria strains, the results reported here can partially explain the popular use of $P$. punctatum as antiseptic by the Toba indigenous population. In addition, due to $S$. aureus is the main food spoilage, and the presence of $P$. aeruginosa in many kind of food is well reported [28,31], microbial biofilm inhibition is an important target in the field of food conservation. Then, besides of the potential uses of pure spicy compounds as antimicrobials in human infections, the not spicy drimanes act as the main active compounds suggesting that the uses of $P$. punctatum as spice can provide beneficial as a food conservative. We report here for the first time the antibiofilm and anti-elastolytic properties of $P$. punctatum against $S$. aureus and $P$. aeruginosa, and demonstrated that isotadeonal (2), which was generally considered biologically inactive, is a strong inhibitor able to control biofilm formation and bacterial growth of both tested kinds of bacteria. The results of this study reinforce the anciet use of the herb as antimicrobial in food

\subsection{Polygodial (1)}

${ }^{1} \mathrm{H}$ NMR $\left(300 \mathrm{MHz}, \mathrm{CDCl}_{3}\right): 9.48(1 \mathrm{H}, d, J=4.2 \mathrm{~Hz}$, $\mathrm{H}-11) ; 9.42(1 \mathrm{H}, s, \mathrm{H}-12) ; 7.11(1 \mathrm{H}, m, \mathrm{H}-7) ; 2.78(1 \mathrm{H}$, dddd, $J=6.2,2.1,2.1,2.1 \mathrm{~Hz}, \mathrm{H}-9) ; 2.55-2.40(1 \mathrm{H}, m$, $\mathrm{H}-6 \alpha) ; 2.35-2.20(1 \mathrm{H}, m, \mathrm{H}-6 \beta) ; 1.82(1 \mathrm{H}, m, \mathrm{H}-1 \beta)$; 1.54-1.43 (3H, $m, \mathrm{H}-2 \alpha, 2 \beta, 3 \beta) ; 1.34(1 \mathrm{H}, t d, J=4.0$ and $13.4 \mathrm{~Hz}, \mathrm{H}-1 \alpha) ; 1.26-1.16(2 \mathrm{H}, m, \mathrm{H}-3 \alpha, \mathrm{H}-5)$; 0.92; $(3 \mathrm{H}, s, \mathrm{Me}-15) ; 0.91$ and $0.89(6 \mathrm{H}, 2 \mathrm{~s}, \mathrm{Me}-14$ and $\mathrm{Me}-$ 15). ${ }^{13} \mathrm{C}$ NMR $\left(75 \mathrm{MHz}, \mathrm{CDCl}_{3}\right): 201.9(\mathrm{HC}=\mathrm{O}) ; 193.2$ $(\mathrm{HC}=\mathrm{O}) ; 154.4(=\mathrm{CH}) ; 138.1(=\mathrm{C}) ; 60.2(\mathrm{CH}) ; 48,8$ $(\mathrm{CH}) ; 41.7\left(\mathrm{CH}_{2}\right) ; 39.5\left(\mathrm{CH}_{2}\right) ; 36.8(\mathrm{C}) ; 33.0(\mathrm{C}) ; 33.0$ $\left(\mathrm{CH}_{3}\right) ; 25.1\left(\mathrm{CH}_{2}\right) ; 21.9\left(\mathrm{CH}_{3}\right) ; 17.9\left(\mathrm{CH}_{2}\right) ; 15.2\left(\mathrm{CH}_{3}\right)$. MS (El, $70 \mathrm{eV}): m / z(\%)=234\left[\mathrm{M}^{+}\right], 216\left[\mathrm{M}^{+}-\mathrm{H}_{2} \mathrm{O}\right]$, $206\left[\mathrm{M}^{+}-\mathrm{CO}\right], 191$ [206- Me].

\subsection{Isotadeonal (2)}

${ }^{1} \mathrm{H}$ NMR $\left(300 \mathrm{MHz}, \mathrm{CDCl}_{3}\right): 9.86(1 \mathrm{H}, d, J=2.7 \mathrm{~Hz}$, $\mathrm{H}-11) ; 9.41(1 \mathrm{H}, \mathrm{s}, \mathrm{H}-12) ; 7.11(1 \mathrm{H}, d d, J=2.7$ and 4.9 $\mathrm{Hz}, \mathrm{H}-7) ; 3.26(1 \mathrm{H}, b m, \mathrm{H}-9) ; 2.57(1 \mathrm{H}, d t, J=5.0,5.0$, $20.6 \mathrm{~Hz}, \mathrm{H}-6 \mathrm{\alpha}) ; 2.22(1 \mathrm{H}, d d d d, J=1.8,2.6,11.6$ and $20.6 \mathrm{~Hz}, \mathrm{H}-6 \beta) ; 1.80(1 \mathrm{H}, m, \mathrm{H}-1 \beta) ; 1.62-1.52(5 \mathrm{H}, m$, $\mathrm{H}-1 \alpha, 2 \alpha, 2 \beta, 3 \beta, 5) ; 1.19(1 \mathrm{H}, d d d, J=0.62,4.1$ and 
$12.0 \mathrm{~Hz}, \mathrm{H}-3 \alpha) ; 0.97(3 \mathrm{H}, \mathrm{s}, \mathrm{Me}-15) ; 0.94$ and $0.92(6 \mathrm{H}$, $2 s$, Me-13 and Me-14). ${ }^{13} \mathrm{C}$ NMR $\left(75 \mathrm{MHz}, \mathrm{CDCl}_{3}\right)$ : $202.2(\mathrm{HC}=\mathrm{O}) ; 192.8(\mathrm{HC}=\mathrm{O}) ; 153.5(=\mathrm{CH}) ; 137.3$ $(=\mathrm{C}) ; 58.5(\mathrm{CH}) ; 44.2(\mathrm{CH}) ; 42.0\left(\mathrm{CH}_{2}\right) ; 37.6\left(\mathrm{CH}_{2}\right)$; $37.1(\mathrm{C}) ; 32.9(\mathrm{C}) ; 32.7\left(\mathrm{CH}_{3}\right) ; 25.5\left(\mathrm{CH}_{2}\right) ; 21.9\left(\mathrm{CH}_{3}\right)$; $21.5\left(\mathrm{CH}_{2}\right) ; 18.4\left(\mathrm{CH}_{3}\right)$. MS (EI, $\left.70 \mathrm{eV}\right): \mathrm{m} / \mathrm{z}(\%)=234$ $\left[\mathrm{M}^{+}\right], 216\left[\mathrm{M}^{+}-\mathrm{H}_{2} \mathrm{O}\right], 206\left[\mathrm{M}^{+}-\mathrm{CO}\right], 191[206-\mathrm{Me}]$.

\section{ACKNOWLEDGEMENTS}

We acknowledge financial supports from ANPCyT, CONICET, and CIUNT (26-D-407), Argentina. Authors would like to thank Lic. Federico Arrighi and Lic. Abel Arroyo Aguilar for its help in recording and analyzing GC/MS data.

\section{REFERENCES}

[1] Wang KJ, Zhang YJ, Yang CR. Antioxidant phenolic compounds from rhizomes of Polygonum paleaceum. J Ethnopharmacol 2005; 96: 483-7. http://dx.doi.org/10.1016/j.jep.2004.09.036

[2] Derita MG, Gattuso SJ, Zacchino SA. Occurrence of polygodial in species of Polygonum genus belonging to Persicaria section. Biochem Syst Ecol 2008; 36: 55-8. http://dx.doi.org/10.1016/j.bse.2007.05.011

[3] López SN, Sierra MG, Gattuso SJ, Furlán RL, Zacchino SA. An unusual homoisoflavanone and a structurally-related dihydrochalcone from Polygonum ferrugineum (Polygonaceae). Phytochemistry 2006; 67: 2152-8. http://dx.doi.org/10.1016/j.phytochem.2006.06.018

[4] Jonassohn M. Sesquiterpenoids unsaturaded dialdehydes. Ph D Thesis, Lunde University 1996.

[5] Kubo I, Fujita K, Lee SH. Antifungal mechanism of polygodial. J Agric Food Chem 2001; 49: 1607-11. http://dx.doi.org/10.1021/jf000136g

[6] Kubo I, Fujita KI, Lee SH, Ha TJ. Antibacterial activity of polygodial. Phytother Res 2005; 19: 1013-7. http://dx.doi.org/10.1002/ptr.1777

[7] Alves TMDA, Ribeiro FL, Kloos H, Zani CL. Polygodial, the Fungitoxic Component from the Brazilian Medicinal Plant Polygonum punctatum. Mem I Oswaldo Cruz 2001; 96: 8313.

\section{http://dx.doi.org/10.1590/S0074-02762001000600016}

[8] Martínez-Crovetto $\mathrm{R}$, Las plantas utilizadas en medicina popular en el noroeste de Corrientes (República Argentina), Ministerio de Cultura y Educación, Tucumán, Argentina, 1981.

[9] Penna C, Marino S, Vivot E, Cruañes MC, De D, Muñoz J, et al. Antimicrobial activity of Argentine plants used in the treatment of infectious diseases. Isolation of active compounds from Sebastiania brasiliensis. J Ethnopharmacol 2001; 77: 37-40.

http://dx.doi.org/10.1016/S0378-8741(01)00266-5

[10] Costerton JW, Stewart PS, Greenberg EP. Bacterial biofilms: A common cause of persistent infections. Science 1999; 284: 1318-22.

http://dx.doi.org/10.1126/science.284.5418.1318

[11] Chmielewski RAN, Ftank JF. Inactivation of Listeria monocytogenes biofilms using chemical sanitizers and heat. In: Blaschek HP, Wang HH, Alge ME, Eds. Biofilms in the Food Environment. lowa: Blackwell Publishing, 2007; pp. 73104.
Paz C, Cárcamo G, Silva M, Becerra J, Urrutia H, Sossa K. Drimendiol, a drimane sesquiterpene with quorum sensing inhibition activity. Nat Prod Comun 2013; 8: 147-8.

[13] Stewart PS, Costerton JW. Antibiotic resistance of bacteria in biofilms. Lancet 2001; 358: 135-8.

http://dx.doi.org/10.1016/S0140-6736(01)05321-1

[14] Sokol PA, Kooi C, Hodges RS, Cachia P, Woods DE. Immunization with a Pseudomonas aeruginosa elastase peptide reduces severity of experimental lung infections due to $P$. aeruginosa or Burkholderia cepacia. J Infect Dis 2000; 181: 1682-92.

http://dx.doi.org/10.1086/315470

[15] O'Toole GA, Kolter R. Flagellar and twitching motility are necessary for Pseudomonas aeruginosa biofilm development. Mol Microbiol 1998; 30: 295-304. http://dx.doi.org/10.1046/j.1365-2958.1998.01062.x

[16] Caballero AR, Moreau JM, Engel LS, Marquart ME, Hill JM, O'Callaghan RJ. Pseudomonas aeruginosa protease IV enzyme assays and comparison to other Pseudomonas proteases. Anal Biochem 2001; 290: 330-7. http://dx.doi.org/10.1006/abio.2001.4999

[17] Mashimbye MJ, Maumela MC, Drewes SE. A drimane sesquiterpenoid lactone from Warburgia salutaris. Phytochemistry 1999; 51: 435-8. http://dx.doi.org/10.1016/S0031-9422(98)00753-5

[18] Asakawa $\mathrm{Y}$, Toyota M, Oiso $\mathrm{Y}$, Braggins JE. Occurrence of polygodial and 1-(2,4,6-trimethoxyphenyl)-but-2-en-1-one from some ferns and liverworts: Role of pungent components in bryophytes and pteridophytes evolution. Chem Pharm Bull 2001; 49: 1380-1.

http://dx.doi.org/10.1248/cpb.49.1380

[19] Cortes MM, Oyarzun LM. Tadeonal and isotadeonal from Drimys winteri. Fitoterapia 1981; 52: 33-5.

[20] Fujita KI, Kubo I. Multifunctional action of antifungal polygodial against Saccharomyces cerevisiae: Involvement of pyrrole formation on cell surface in antifungal action. Bioorg Med Chem 2005; 13: 6742-7. http://dx.doi.org/10.1016/j.bmc.2005.07.023

[21] Bastos JK, Kaplan MAC, Gottlieb OR. Drimane-Type Sesquiterpenoids as Chemosystematic Markers of Canellaceae. J Brazil Chem Soc 1999; 10.

[22] Derita MG, Leiva ML, Zacchino SA. Influence of plant part, season of collection and content of the main active constituent, on the antifungal properties of Polygonum acuminatum Kunth. J Ethnopharmacol 2009; 124: 377-83. http://dx.doi.org/10.1016/j.jep.2009.05.029

[23] Taniguchi M, Adachi T, Oi S, Kimura A, Katsumara S, Isoe S, et al. Structure-Activity Relationship of the Warburgia Sesquiterpene Dialdehydes. Agr Biol Chem Tokyo 1984; 48: 73-8.

http://dx.doi.org/10.1271/bbb1961.48.73

[24] Lunde CS, Kubo I. Effect of Polygodial on the Mitochondrial ATPase of Saccharomyces cerevisiae. Antimicrob Agents Chemother 2000; 44: 1943-53. http://dx.doi.org/10.1128/AAC.44.7.1943-1953.2000

[25] Song JH, Yang TC, Chang KW, Han SK, Yi HK, Jeon JG. In vitro effects of a fraction separated from Polygonum cuspidatum root on the viability, in suspension and biofilms, and biofilm formation of mutans streptococci. J Ethnopharmacol 2007; 112: 419-25. http://dx.doi.org/10.1016/j.jep.2007.03.036

[26] Cowan MM. Plant products as antimicrobial agents. Clin Microbiol Rev 1999; 12: 564-82.

[27] Smith JE, Tucker D, Watson K, Jones GL. Identification of antibacterial constituents from the indigenous Australian medicinal plant Eremophila duttonii F. Muell. (Myoporaceae). J Ethnopharmacol 2007; 112: 386-93.

http://dx.doi.org/10.1016/j.jep.2007.03.031 
[28] Sandasi M, Leonard CM, van Vuuren SF, Viljoen AM. Peppermint (Mentha piperita) inhibits microbial biofilms in vitro. S Afr J Bot 2011; 77: 80-5. http://dx.doi.org/10.1016/j.sajb.2010.05.011

[29] Gilabert M, Ramos AN, Schiavone MM, Arena ME, Bardón A. Bioactive sesqui- and diterpenoids from the argentine liverwort Porella chilensis. J Nat Prod 2011; 74: 574-9. http://dx.doi.org/10.1021/np100472d

[30] Anke H, Stern O. Comparison of the antimicrobial and cytotoxic activities of twenty unsaturated sesquiterpene dialdehydes from plants and mushrooms. Planta Med 1991; 57: 344-6.

http://dx.doi.org/10.1055/s-2006-960114

[31] Eneroth A, Ahrne S, Molin G. Contamination routes of Gramnegative spoilage bacteria in the production of pasteurised milk, evaluated by randomly amplified polymorphic DNA (RAPD). International Dairy Journal 2000; 10: 325-31. http://dx.doi.org/10.1016/S0958-6946(00)00055-8

DOI: http://dx.doi.org/10.15377/2409-9813.2014.01.01.1

(c) 2014 Gilabert et al.; Avanti Publishers.

This is an open access article licensed under the terms of the Creative Commons Attribution Non-Commercial License (http://creativecommons.org/licenses/by-nc/3.0/) which permits unrestricted, non-commercial use, distribution and reproduction in any medium, provided the work is properly cited. 